\title{
Iridodonesis as a cause of recurrent vertigo
}

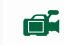

Supplemental data at Neurology.org
A 56-year-old woman complained of recurrent attacks of vertigo. Attacks lasted no longer than a second and could be easily provoked by abrupt eye movements. Vertigo disappeared when the left eye was covered. Symptoms had begun after left-sided cataract surgery resulting in subluxation of the left lens. The characteristic feature of iridodonesis is the tremulousness of the iris with eye movement (video on the Neurology ${ }^{\circledR}$ Web site at Neurology.org). While in many cases iridodonesis is asymptomatic, we speculate that in our patient, the instability of the optical system results in a trembling image on the retina, which, in turn, causes irritation in downstream brain regions.

Hagen Kunte, MD, Friedemann Paul, MD, Florence Pache, MD, Jan Dörr, MD, Judith Bellmann-Strobl, MD, Lutz Harms, MD, Golo Kronenberg, MD

From NeuroCure Clinical Research Center (H.K., F. Paul, F. Pache, J.D., J.B.-S.) and Charité Center 15 for Neurology, Neurosurgery and Psychiatry (L.H., G.K.), Charité-Universitätsmedizin Berlin; and Experimental and Clinical Research Center (J.B.-S.), Max Delbrück Center for Molecular Medicine, Berlin, Germany.

Study funding: No targeted funding reported.

Disclosure: The authors report no disclosures relevant to the manuscript. Go to Neurology.org for full disclosures.

Correspondence to Dr. Kunte: hagen.kunte@charite.de

\section{WriteClick ${ }^{\circledR}$ rapid online correspondence}

The editors encourage comments about recent articles through WriteClick:

Go to Neurology.org and click on the "WriteClick" tab at the top of the page. Responses will be posted within 72 hours of submission.

Before using WriteClick, remember the following:

- WriteClick is restricted to comments about studies published in Neurology within the last eight weeks

- Read previously posted comments; redundant comments will not be posted

- Your submission must be 200 words or less and have a maximum of five references; reference one must be the article on which you are commenting

- You can include a maximum of five authors (including yourself) 


\title{
Neurology
}

\author{
Iridodonesis as a cause of recurrent vertigo \\ Hagen Kunte, Friedemann Paul, Florence Pache, et al. \\ Neurology 2015;85;1353 \\ DOI 10.1212/WNL.0000000000002025
}

This information is current as of October 12, 2015

\begin{tabular}{|c|c|}
\hline $\begin{array}{l}\text { Updated Information \& } \\
\text { Services }\end{array}$ & $\begin{array}{l}\text { including high resolution figures, can be found at: } \\
\text { http://n.neurology.org/content } / 85 / 15 / 1353 \text {.full }\end{array}$ \\
\hline Supplementary Material & $\begin{array}{l}\text { Supplementary material can be found at: } \\
\text { http://n.neurology.org/content/suppl/2015/10/10/WNL.0000000000002 } \\
\text { 025.DC1 }\end{array}$ \\
\hline Subspecialty Collections & $\begin{array}{l}\text { This article, along with others on similar topics, appears in the } \\
\text { following collection(s): } \\
\text { Clinical neurology examination } \\
\text { http://n.neurology.org/cgi/collection/clinical_neurology_examination } \\
\text { Nystagmus } \\
\text { http://n.neurology.org/cgi/collection/nystagmus } \\
\text { Ocular motility } \\
\text { http://n.neurology.org/cgi/collection/ocular_motility } \\
\text { Vertigo } \\
\text { http://n.neurology.org/cgi/collection/vertigo }\end{array}$ \\
\hline Permissions \& Licensing & $\begin{array}{l}\text { Information about reproducing this article in parts (figures,tables) or in } \\
\text { its entirety can be found online at: } \\
\text { http://www.neurology.org/about/about_the_journal\#permissions }\end{array}$ \\
\hline Reprints & $\begin{array}{l}\text { Information about ordering reprints can be found online: } \\
\text { http://n.neurology.org/subscribers/advertise }\end{array}$ \\
\hline
\end{tabular}

Neurology ${ }^{\circledR}$ is the official journal of the American Academy of Neurology. Published continuously since 1951, it is now a weekly with 48 issues per year. Copyright (C 2015 American Academy of Neurology. All rights reserved. Print ISSN: 0028-3878. Online ISSN: 1526-632X.

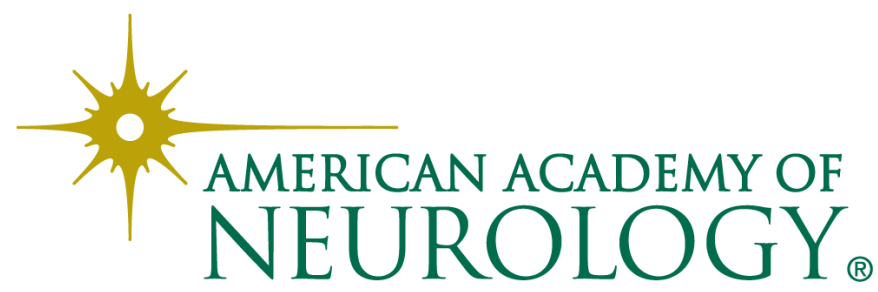

